\title{
HUBUNGAN ANTARA KADAR TGF-B1 DENGAN KADAR ALBUMIN DALAM URIN PASIEN DM TIPE-2 DENGAN NEFROPATI DIABETIK
}

\author{
Elfiani $^{1}$, Rita Halim ${ }^{2}$, M. Haldian Hakir $^{3}$ \\ ${ }^{1}$ Staf Dosen FKIK UNJAVDokter Penyakit Dalam RSUD Raden Mattaher \\ ${ }^{2}$ Staf Dosen FKIK UNJA/Bagian ilmu Gizi klinik FKIK UNJA \\ ${ }^{3}$ Dokter Muda Penyakit Dalam RSUD Raden Mattaher \\ Email: elfiani@gmail.com
}

\begin{abstract}
Background: Diabetic nephropathy $(D N)$ is a complication of diabetes in the kidney that frequently causes terminal kidney disease. This kidney disease caused by diabetes is a syndrome characterized by albumin in urine (albuminuria). Growth factor- $\beta 1$ (TGF- $\beta 1$ ) is a multifunctional cytokine that controls many biological processes, including immunity, differentiation, tumor suppression, tumor metastasis, aging, migration, wound healing, apoptosis, adipogenesis, and osteogenesis. Previous studies had showed that TGF- $\beta 1$ plays a role in albuminuria, where TGF- $\beta 1$ expression in the kidney increases in diabetes patients. Elevation of cytokine level, especially transforming growth factor beta-1 (TGF- $\beta 1$ ) that induces the increase of several extra cellular matrices (ECM), i.e. fibronectin, integrin-linked kinase (ILK) and type IV collagen. This TGF- $\beta 1$ activity causes the accumulation of ECM, which leads to thickened glomerular basement membrane (GBM). Thickening of GBM and changes in kidney structure in the form of hypertrophy and reduced glomerular podocytes caused by apoptosis and attachment in GBM causes protein components to exit through urine (albuminuria). This study aimed to prove the correlation between transforming growth factor- $\beta 1$ and albumin level in urine of diabetic nephropathy.

Metode : This study a observasional with desain Cross-sectional comparative study.

Results: Mean TGF- $\beta 1$ level in type 2 DM patients with diabetic nephropathy in this study was $47.30 \pm$ $14.70 \mathrm{ng} / \mathrm{ml}$, with similar value between men and women with $43.1 \mathrm{ng} / \mathrm{ml}$ and $44.7 \mathrm{ng} / \mathrm{ml}$, respectively. Out of 60 type 2 DM participants with ND, the mean albuminuria level according to ACR was $722.53 \pm 1854.96$ $\mathrm{mg} / \mathrm{g}$. The result of male participants was lower compared to female participants, with $667.8 \mathrm{mg} / \mathrm{mg}$ and $777.2 \mathrm{mg} / \mathrm{g}$, respectively.

Conclusion: There was insignificant correlation between TGF- $\beta 1$ in diabetic nephropathy (DN) and albumin level in urine measured using albumin and urine creatinine ratio $(A C R)(p=0.066)$.
\end{abstract}

Keywords: Diabetic Nephropathy, Albuminuria, TGF- $\beta 1$

ABSTRAK

Latar Belakang : Nefropati diabetik (ND) merupakan komplikasi diabetes pada ginjal yang paling sering menyebabkan terjadinya penyakit ginjal terminal. Penyakit ginjal akibat diabetes ini merupakan sindroma dengan karakteristik terdapatnya albumin dalam urine (albuminuria). Faktor pertumbuhan- $\beta 1$ (TGF- $\beta 1$ ) adalah sebuah sitokin multifungsi yang mengendalikan banyak proses biologis termasuk kekebalan, diferensiasi, tumor supresi, tumor metastasis, penuaan, migrasi, penyembuhan luka, apoptosis, adipogenesis, dan osteogenesis. Sejumlah penelitian sebelumnya menunjukkan bahwa TGF- $\beta 1$ berperan 
terhadap terjadinya albuminuria, dimana pasien diabetes didapatkan ekspresi TGF- $\beta 1$ di ginjal meningkat. Peningkatan kadar cytokine terutama Transforming Growth Factor Beta-1 (TGF- $\beta 1$ ) yang menginduksi peningkatan beberapa Extra Cellular Matrix (ECM) antara lain fibronectin, integrin-linked kinase (ILK) dan collagen tipe-IV. Aktifitas TGF- $\beta 1$ ini menyebabkan akumulasi ECM sehingga terjadi penebalan Glomerular Basement Membrane (GBM). Penebalan dari GBM dan terjadinya perubahan struktur ginjal berupa hipertrofi dan berkurangnya sel-sel podocyte glomerulus akibat kerusakan (apoptosis) dan perlengketan di GBM menyebabkan komponen protein keluar melalui urin (albuminuria). Tujuan penelitian ini untuk membuktikan hubungan antara kadar transforming growth factor- $\beta 1$ dengan kadar albumin dalam urin pada Nefropati Diabetik.

Metode : Penelitian ini merupakan penelitian Observasional dengan desain Cross-sectional comparative study.

Hasil : Kadar rata-rata TGF- $\beta 1$ pasien DM tipe-2 dengan Nefropati Diabetik pada penelitian ini adalah $47,30 \pm 14,70 \mathrm{ng} / \mathrm{ml}$, tidak jauh berbeda antara laki-laki yaitu 43,1 ng/ml dengan perempuan 44,7 $\mathrm{ng} / \mathrm{ml}$. Dari 60 orang responden DM tipe-2 dengan ND pada penelitian ini didapatkan kadar albuminuria rata-rata berdasarkan ACR adalah 722,53 $\pm 1854,96 \mathrm{mg} / \mathrm{g}$. Responden laki-laki lebih rendah dibanding perempuan yaitu $667,8 \mathrm{mg} / \mathrm{g}$ berbanding $777,2 \mathrm{mg} / \mathrm{g}$.

Kesimpulan : Tidak terdapat hubungan yang bermakna antara TGF- $\beta 1$ pada Nefropati Diabetik (ND) dengan kadar albumin dalam urin yang dihitung berdasarkan rasio albumin dan creatinin urin (ACR) $(p=0,066)$.

Kata Kunci : Nefropati Diabetik, Albuminuria, TGF- $\beta 1$

\section{PENDAHULUAN}

Nefropati Diabetik (ND) sering didefinisikan sebagai sebuah sindroma klinis yang ditandai dengan terdapatnya albumin dalam urin yang menetap (albuminuria persisten), penurunan laju filtrasi glomerolus (LFG), dan peningkatan tekanan darah arterial. Diagnosis ND ditegakkan bila terdapat albuminuriapersisten> 300 mg/24 jam pada minimal $2 x$ pemeriksaan berturut-turut dalam waktu 3-6 bulanterpisah. Albuminuria ini akan berlanjut menjadi proteinuria akibat hiperfiltrasi patogenik, kerusakan ginjal pada tingkat glomerulus. Pada DM akibat glikasi nonenzimatik dan terbentuknya Advanced Glication End products (AGE's) yang irreversible menyebabkan hipertrofi sel-sel di glomerulus (podocyte) dan meningkat kemoatraktan dari mononuklear serta inhibisi sintesis nitric oxide sebagai vasadilator sehingga terjadi peningkatan tekanan intraglomerulus. Bila terjadi terusmenerus dan terdapat inflamasi kronik seperti nefritis yang reversible akan mengakibatkan terjadi nefropati dimana terjadi kerusakan menetap dan berkembang menjadi chronic kidney disease. Komplikasi inilah yang akan dibahas dalam penelitian ini, komplikasi ginjal pada DM ini terjadi pada $40 \%$ dari seluruh pasien DM tipe 1 dan tipe 2 . Nefropati Diabetik merupakan penyebab utama penyakit ginjal stadium akhir di seluruh dunia. $^{1,2}$

\section{Peran TGF-ß1 pada Nefropati Diabetik}


Faktor pertumbuhan- $\beta 1 \quad$ (TGF- $\beta 1)$ adalah sebuah sitokinional multifungsi yang mengendalikan banyak proses biologis termasuk kekebalan, diferensiasi, tumor supresi, tumor metastasis, penuaan, migrasi, penyembuhan luka, apoptosis, sel divisi, adipogenesis, dan osteogenesis. Selain itu, ekspresi ginjal TGF- $\beta 1$ mRNA dan protein meningkat pada pasien diabetes melitus, dan meningkatkan sintesis dan cross-linking ekstraselular matriks (ECM). Polimorfisme T869C pada gen TGF- $\beta 1$ manusia, yang menyebabkan varian L10P dari protein pengkodean, dikaitkan dengan peningkatan risiko nefropati diabetik, tapi bagaimana caranya perubahan fungsional pada protein TGF- $\beta 1$ meningkatkan kejadian banyak nefropati diabetes tetap sulit dipahami. ${ }^{3}$

Pada nefropati diabetik yang baru terjadi, filtrasi glomerulus rate (GFR) meningkat sebesar 25-50\% (hiperfiltrasi glomerular) dengan pengurangan umpan balik tubuloglomerular, disebabkan oleh peningkatan reabsorbsi sodium / glukosa dan Oleh karena itu pengiriman sodium berkurang di makula densa. Namun, pada tahap akhir nefropati diabetik, GFR akhirnya menurun seiring jumlah nefron fungsional menurun, yang menyebabkan ketidakcukupan fungsi ekskresi ginjal. Penurunan GFR dikaitkan dengan ekspansi daerah mesangial, yang disebabkan oleh proliferasi sel dan akumulasi ECM. Meski terjadi peningkatan ekskresi albumin dalam urine dianggap sebagai indikator awal nefropati diabetik, mekanisme dimana hiperbuminuria terjadi pada diabetes tidak sepenuhnya dipahami. Namun, penurunan nilai fungsi penghalang pada celah diafragma antara podosit dan Penurunan reabsorpsi albumin yang disaring oleh proksimal tubulus barubaru ini telah diidentifikasi penting dalam pengembangan albuminuria diabetes. Temuan sebelumnya menunjukkan bahwa TGF- $\beta 1$ memainkan peran fisiologis tidak hanya dalam mempromosikan glomerulosklerosis, fibrosis interstisial, dan penurunan GFR tetapi juga pada peningkatan ekskresi albumin, air, elektrolit, dan glukosa pada diabetes.

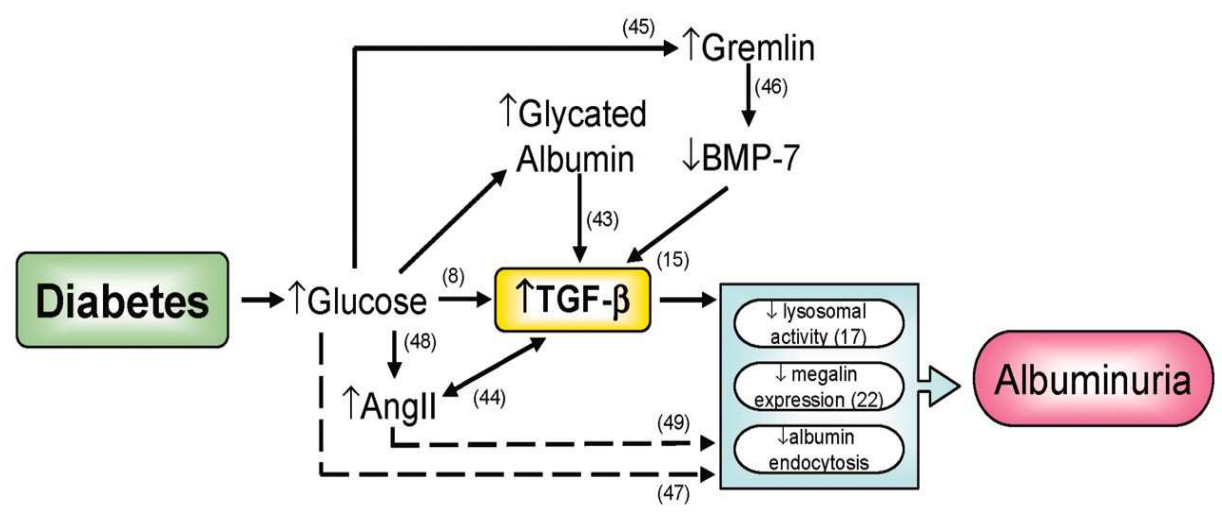

Gambar 1 Peran TGF- $\beta$ pada kejadian albuminuria (Chang AS et al., 2015) 
Penelitian sebelumnya menunjukkan bahwa antibodi anti-TGF- $\beta$ yang menetralisir dan mencegah glomerulosklerosis serta fibrosis interstisial. Peningkatan ekspresi TGF- $\beta 1$ pada penelitian sebelumnya telah menunjukkan bahwa TGF- $\beta 1$ mperangsang transkripsi komponen ECM, termasuk collagen, fibronektin, dan laminin. Jadi TGFß1 memfasilitasi akumulasi ECM dengan meningkatkan produksi dan stabilisasi ECM dan dengan menekan degradasinya, yang memainkan peran penting dalam pengembangan glomerulosklerosis dan fibrosis interstisial pada Nefropati Diabetik. TGF-ß1 menurunkan kadar mRNA ginjal nephrin dan meningkatkan permeabilitas albumin di podocyte. Hasil percobaan dengan spesifik jaringan TGF- $\beta 1$ menunjukkan bahwa menekan ekspresi TGF- $\beta 1$ di tubulus proksimal lebih cenderung menurunkan albuminuria dan fibrosis interstisial. Dengan mengurangi ekspresi TGF- $\beta 1$ di podocyte efektif menghindari penurunan $\mathrm{GFR}^{4}$

\section{Diagnosis Nefropati Diabetik}

Konsensus PERKENI (Perkumpulan Endokrinologi Indonesia) tahun 2015 telah menetapkan untuk menegakan diagnosis ND secara klinis adalah dengan didapatkannya kadar albumin > $30 \mathrm{mg}$ dalam urin 24 jam pada 2 dari 3 pemeriksaan dalam kurun waktu 3-6 bulan tanpa penyebab albuminuria lainnya. Klasifikasi nefropati diabetik dibagi atas albuminuria persisten level 30-299 $\mathrm{mg} / 24$ jam dan albuminuria persisten pada level $\geq 300 \mathrm{mg} / 24$ jam.

Albuminuria dipertimbangkan sebagai penanda yang sensitif dari penyakit ginjal kronis dan resiko kardiovaskular, dan saat ini digunakan sebagai indikator klinis pertama dari penyakit ginjal pada diabetik. Pengukuran kadar albumin dalam urin 24 jam merupakan baku emas dari diagnosis ND namun pada kenyataannya sulit untuk melakukan pengambilan sampel urin. Barubaru ini, guideline merekomendasikan penggunaan rasio Albumin-to-creatinin (ACR) pada sampel urin sewaktu (a spot urine sampel), sebuah teknik yang dapat dilakukan dengan mudah pada setting klinis sebagai pengganti dari albumin urin pada pengumpulan urin 24 jam. $^{5}$

Berdasarkan ACR, pasien diklasifikasikan menjadi 3 kategori albuminuria dari Kidney Disease Improving Global Outcomes (KDIGO) yaitu A1, A2, dan A3. Normal-ataupeningkatan albuminuria ringan (A1) diartikan sebagai kreatinin $<30 \mathrm{mg} / \mathrm{g}$ dan peningkatan albuminuria sedang (A2) didefinisikan sebagai kreatinin 30-300 $\mathrm{mg} / \mathrm{g}$ dan pasien dengan ACR lebih besar $300 \mathrm{mg} / \mathrm{g}$ dikategorikan sebagai peningkatan albuminuria berat (A3), yang dahulu disebut makroalbuminuria. American Diabetes Association (ADA) merekomendasikan bahwa kriteria seorang penderita DM telah terjadi ND bila terdapat albuminuria ketika 2 dari 3 pengukuran ACR menunjukkan hasil abnormal dalam waktu 6 bulan. Progresi dari kategori A2 ke A3 diprediksi naik 2-3\% per tahun, dan hal ini dihubungkan dengan penurunan LFG. (Laju Filtrasi Glomerulus) atau eGFR (Glomerular Filtration Rate). Walaupun GFR hanyalah satu komponen dari fungsi ekskretori ginjal, hal ini secara umum diterima sebagai indeks terbaik dari penilaian fungsi ginjal karena biasanya LFG berkurang setelah terdapat kerusakan struktural yang luas dari sel-sel podosit di 
glomerulus. Walaupun adanya albumin dalam urin dikenali sebagai penanda awal dari ND tetapi kerusakan glomerular yang signifikan telah terjadi saat albuminuria muncul. Sehingga beberapa biomarker baru berdasarkan proteomic diinvestigasi dengan harapan mengatasi keterbatasan dari alat diagnostik ND. ${ }^{5}$

Pemeriksaan mikroalbuminuria penting dilakukan pada pasien diabetes melitus yang dicurigai mengalami nefropati diabetik. Pada stadium awal terjadi hipertrofi ginjal, hiperfungsi, dan penebalan dari membran glomerulus dan tubulus. Pada stadium ini belum ada gejala klinis yang mengarah kepada gangguan fungsi ginjal, namun proses glomerulosklerosis terus terjadi selama 7-10 tahun ke depan dan berakhir dengan peningkatan permeabilitas dari glomerulus. Peningkatan permeabilitas ini menyebabkan albumin dapat lolos dari filtrasi glomerulus dan ditemukan pada urin.

Pemeriksaan deteksi awal gangguan fungsi ginjal dan untuk menegakkan diagnosis nefropati diabetik pada penderita DM tipe 2 yang direkomendasikan International Society Nephrology (ISN)adalah albumin excretion rate atau Urinary Albumin Creatinine Ratio (UACR) karena lebih nyaman, cepat dan tidak memerlukan persiapan khusus. Selain itu juga lebih awaluntuk pemantauan terapi karena ternyata dapat mengoreksi variasi hasil pemeriksaan. Keuntungan pemeriksaan UACR lainnya adalah menggunakan urine sewaktu, sehingga penderita tidak perlu mengumpulkan urine selama 24 jam yang lebih banyak faktor kesalahannya., Pemeriksaan ACR dapat dilakukan dengan memasukkan hasil kadar albumin urin dan kreatinin urin pada rumus:

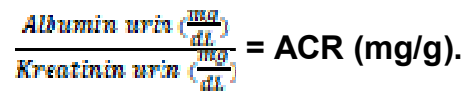

\section{Metode Penelitian}

Penelitian ini merupakan penelitian Observasional dengan desain Crosssectional comparative study.

\section{Tempat penelitian}

Poliklinik dan bangsal Penyakit Dalam serta unit Hemodialisa (HD) : Rumah Sakit Umum Daerah Raden Mattaher Jambi, RS Pertamedika Baiturrahim Jambi, RS MMC (Mayang Medical Center) Jambi. Pengambilan sampel darah dan urin sewaktu pasien DM tipe-2 dilakukan di Laboratorium Prodia : Pengambilan sampel darah dan urin dari pasien DM tipe-2 untuk pemeriksaan ACR dari urin sewaktu dan pemeriksaan kadar TGF- $\beta 1$ dari serum darah pasien, dilakukan oleh tenaga laboratorium yang telah dilatih. Sampel urin dan serum darah pasien dikirim ke laboratorium PRODIA Jakarta guna pemeriksaan kadar TGF- $\beta 1$ dan pemeriksaan ACR urin.

\section{Waktu penelitian}

Dilakukan selama 1 tahun

\section{Populasi dan Sampel Penelitian}

Populasi dan sampel dari penelitian ini adalah pasien DM tipe-2 yang berobat di poliklinik penyakit dalam Rumah Sakit Umum Daerah Raden Mattaher Jambi yang didiagnosis ND sesuai PERKENI tahun 2015, dan sebagai pembanding/kontrol adalah pasien DM tipe-2 tanpa ND.

Kriteria ND adalah terjadinya albuminuria persisten, dimana terdapat albumin dalam urin pada 2 dari 3 pengukuran diwaktu yang berbeda dalam waktu 6 berdasarkan metoda 
pemeriksaan Albumin-Creatinin Rasio (ACR). Penilaian ACR dilakukan dengan menghitung kadar albumin yang dibandingkan dengan kadar creatinin dalam urin sewaktu sampel yang memenuhi kriteria inklusi dan eklusi. Kriteria inklusi terdiri dari pasien berusia 20 60 tahun, bersedia mengikuti penelitian ini dengan menanda tangani inform consent. Kriteria ekslusi pasien menderita infeksi saluran kemih, pasien DM dengan penyakit ginjal lain, hamil, pasien dengan penyakit autoimun.

\section{Besar dan Teknik Pengambilan Sampel}

Besar sampel dihitung dengan menggunakan rumus uji hipotesis (2 arah) terhadap perbedaan 2 .

Jadi didapatkan perkiraan minimal sampel adalah 23 orang, untuk menghindari drop out ditambah $10-20 \%$ sehingga digenapkan menjadi 30 orang untuk kelompok DM tipe-2 tanpa ND (kontrol) dan 30 penderita DM tipe2 dengan ND (kasus). Responden pada penelitian ini berjumlah 60 orang yang terdiri dari 30 orang laki-laki dan 30 orang perempuan dengan usia rata-rata sama yaitu 49,1 tahun.

\section{Hasil}

Hasil dari pemeriksaan laboratorium kreatinin, Laju Filtrasi Glomerulus (LGF), kadar Albumin Creatinin Ratio (ACR) dan kadar serum TGF- $\beta 1$ dari responden tampak pada Tabel 1 Rataan Hasil Pemeriksaan Laboratorium berdasarkan jenis kelamin.

Tabel 1 Rataan Hasil Pemeriksaan Laboratorium berdasarkan jenis kelamin.

\begin{tabular}{|c|l|c|c|c|c|c|}
\hline Jlh & Jenis Kelamin & Umur & Kreatinin & LFG & $\begin{array}{c}\text { ACR } \\
(\mathrm{mg} / \mathrm{g})\end{array}$ & $\begin{array}{c}\text { TGF- } \beta \\
(\mathrm{ng} / \mathrm{ml})\end{array}$ \\
\hline 30 & Laki-laki & $49,1 \pm 8,62$ & $0,7 \pm 0,58$ & $83,3 \pm 45,61$ & $667,8 \pm 1245,53$ & $43,1 \pm 15,17$ \\
\hline 30 & Perempuan & $49,2 \pm 9,71$ & $0,8 \pm 1,66$ & $97,4 \pm 39,28$ & $777,2 \pm 2333,01$ & $44,7 \pm 14,44$ \\
\hline & & & & & & \\
\hline
\end{tabular}

Berdasarkan tabel 1 didapatkan kadar kreatinin responden masih normal yaitu dibawah 1 dengan LGF masih normal diatas $60 \%$. Sedangkan kadar albuminuria rata-rata dari nilai ACR pada responden laki-laki lebih rendah dibanding perempuan yaitu 667,8 \pm 1245,53 berbanding $777,2 \pm 2333,01$, dan terlihat bahwa kadar albuminuria ini sangat variatif dengan SD (Standar Deviasi) yang cukup lebar baik pada laki-laki maupun perempuan. Sedangkan kadar TGF- $\beta 1$ ratarata laki-laki hampir sama dengan perempuan.
Pada penelitian ini didapatkan pasien DM tipe-2 dengan nilai ACR normal atau belum dikategorikan mengalami Nefropati Diabetik (ND) atau kategori A1 sebanyak 25 orang yaitu 15 orang perempuan dan 10 orang lakilaki. Sedangkan yang telah mengalami ND sebanyak 35 orang yaitu 20 orang dengan kategori A2 atau mikro-albuminuria yang terdiri dari 10 orang laki-laki dan 10 orang perempuan, dan 15 orang dengan makroalbuminuria atau kategori A3 (10 orang lakilaki dan 5 orang perempuan). 
Pada tabel 2 juga terlihat peningkatan yang sangat tinggi rerata kadar albumin di urin (albuminuria) kategori A3 bila dibandingkan dengan peningkatan rerata albuminuria kategori A2 dari kategori A1. Hal ini menunjukan bahwa fungsi reabsorsi dan filtrasi glomerulus terhadap molekul dengan ukuran besar (protein/albumin) pada pasien ND kategori A3 sudah sangat terganggu.

Tabel 2 Rataan Hasil Pemeriksaan Laboratorium berdasarkan Kategori ND.

\begin{tabular}{|l|c|c|c|c|c|}
\hline Kategori ND & Umur (th) & $\begin{array}{c}\text { Kreatinin } \\
(\mathrm{mg} \%)\end{array}$ & LFG & ACR & TGF- $\beta 1$ \\
\hline Normal/A1 & $47,8 \pm 11,10$ & $0,5 \pm 0,41$ & $110,5 \pm 21,91$ & $11,5 \pm 7,43$ & $46,0 \pm 14,61^{a}$ \\
\hline Mikro-alb/A2 & $47,2 \pm 7,41$ & $0,6 \pm 0,52$ & $96,6 \pm 36,69$ & $103,6 \pm 83,62$ & $47,3 \pm 16,46^{a}$ \\
\hline Makro-alb/A3 & $53,8 \pm 5,63$ & $1,4 \pm 2,22$ & $48,3 \pm 48,95$ & $2732,8 \pm 2951,55$ & $36,0 \pm 9,32^{b}$ \\
\hline
\end{tabular}

TGF- $\beta 1$ dengan ACR pada 60 orang pasien DM tipe-2 dari penelitian ini dapat dilihat Peningkatan kadar rerata TGF- $\beta 1$ pada kelompok kategori A2 dibanding kelompok kategori A1 tidak bermakna ( $p>0,05)$, akan tetapi pada kategori A3 terjadi penurunan rerata kadar TGF- $\beta 1$ dibandingkan kelompok kategori A1/normal dan kategori A2/miro-albuminuria secara bermakna $(p<$
$0,05)$. Kondisi ini menunjukan bahwa pada ND kategori A3 (makro-albuminuria) telah berkurang ekspresi dari TGF- $\beta 1$ sebagai faktor pertumbuhan dan telah terjadi induksi fibrosis interstisial renal serta peningkatan ekstra celluler matriks (ECM) yang menyebabkan gangguan filtrasi glomerulus pada DM tipe-2 dengan ND.

Tabel 3 Hubungan Kategori ACR dengan Kadar TGF- $\beta 1$

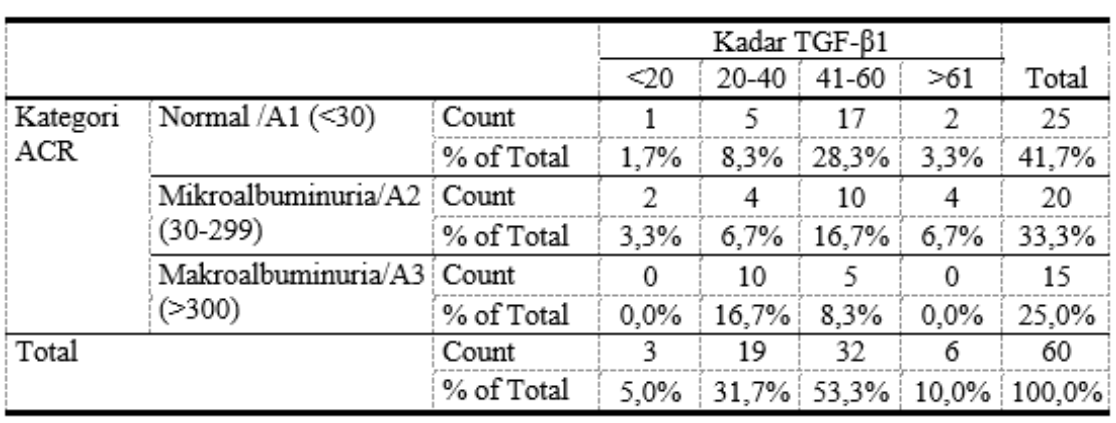

Dari tabel 3 dapat dilihat bahwa dari 25 orang pasien DM tipe-2 dengan ND dengan nilai ACR normal (A1), paling banyak yaitu 17 orang diantaranya memiliki TGF- $\beta 1$ antara 41-60 ng/ml. Sama halnya untuk 20 orang pasien ND dengan mikroalbuminuria/A2, juga terbanyak yaitu 10 orang memiliki kadar TGF- $\beta 1$ antara 41-
$60 \mathrm{ng} / \mathrm{ml}$. Sedangkan pada 15 orang pasien ND kategori makroalbuminuria/A3 hanya 5 orang dengan kadar TGF- $\beta 1$ antara 41-60 $\mathrm{ng} / \mathrm{ml}$, sebagian besar yaitu 10 orang sudah memiliki kadar TGF- $\beta 1$ lebih rendah yaitu antara 20-40 ng/ml. Kadar rerata TGF- $\beta 1$ sebagai faktor pertumbuhan sudah menurun ekspresinya pada pasien ND 
kategori A3 (makro-albuminuria). Hal ini menunjukkan bahwa telah terjadi gangguan filtasi glomerulus yang berakibat semakin tinggi kadar albumin di urin. Untuk rata-rata, median, SD, minimun dan maksimum TGF$\beta 1$ berdasarkan ACRnya dapat dilihat pada tabel 4

Tabel 4. Rerata, median, SD, minimun dan maksimum TGF- $\beta 1$ berdasarkan ACR

\begin{tabular}{|c|c|c|c|}
\hline ACR & Normal $(<30)$ & $\begin{array}{c}\text { Mikroalbuminuria } \\
(30-300)\end{array}$ & $\begin{array}{c}\text { Maroalbuminuria } \\
(>300)\end{array}$ \\
\hline $\mathrm{N}$ & 25 & 20 & 15 \\
\hline Mean & 45,9744 & 47,3045 & 35,9853 \\
\hline Median & 47,68 & 49,965 & 37 \\
\hline Minimum & 14,60712 & 16,45999 & 9,31609 \\
\hline Maksimum & 3,01 & 4,42 & 23,54 \\
\hline
\end{tabular}

Pada tabel 4 menunjukan pada pasien DM tipe-2 dengan ND kategori makroalbuminuria memiliki minimum TGF$\beta 1$ paling besar yaitu 23,54 dibandingkan TGF- $\beta 1$ minimum pada pasien DM tipe-2 tanpa ND atau kategori A1/normal dan A2/mikroalbuminuria. Namun, jika dilihat dari rerata TGF- $\beta 1$ pada kategori makroalbuminuria lebih kecil dibandingkan rerata TGF- $\beta 1$ pada kategori normal dan mikroalbuminuria.

Untuk melihat adakah hubungan antara TGF- $\beta 1$ dengan ACR pada pasien DM tipe 2 dengan nefropati diabetik dilakukan analisis korelasi Pearson yang hasilnya tercantum pada tabel 5

Tabel 5. Hubungan antara TGF- $\beta 1$ dengan ACR pada pasien DM tipe 2 dengan ND

\begin{tabular}{|l|c|c|c|}
\hline & & $\begin{array}{c}\text { Albumin } \\
\text { Kreatinin } \\
\text { Rasio }\end{array}$ & TGF- $\beta 1$ \\
\hline $\begin{array}{l}\text { Albumin Kreatinin } \\
\text { Rasio }\end{array}$ & Pearson Correlation & 1 & $-0,239$ \\
\hline & Sig.(2-tailed) & & 0,066 \\
\hline & $\mathrm{N}$ & 60 & 60 \\
\hline TGF- $\beta 1$ & Pearson Correlation & $-0,239$ & 1 \\
& Sig.(2-tailed) & 0,066 & \\
& $\mathrm{~N}$ & 60 & 60 \\
\hline
\end{tabular}

Hasil dari analisis korelasi Pearson pada tabel 5 didapatkan nilai signifikansinya $p=0,066 \quad(p>0,05)$ yang berarti tidak terdapat hubungan yang bermakna antara TGF-ß1 pada Nefropati Diabetik (ND) dengan kadar albumin dalam urin yang dihitung berdasarkan rasio albumin dan creatinin urin (ACR). Penelitian ini memiliki hasil yang sama dengan penelitian Mehta, 2017 tidak terdapat hubungan antara TGF- $\beta 1$ pada Nefropati Diabetik (ND) dengan kadar albumin.

\section{Kesimpulan}

1. Kadar rata-rata TGF- $\beta 1$ pasien DM tipe-2 dengan Nefropati Diabetik pada penelitian ini adalah 47,30 \pm $14,70 \mathrm{ng} / \mathrm{ml}$, tidak jauh berbeda 
antara laki-laki yaitu $43,1 \mathrm{ng} / \mathrm{ml}$ dengan perempuan $44,7 \mathrm{ng} / \mathrm{ml}$.

2. Dari 60 orang responden DM tipe-2 dengan ND pada penelitian ini didapatkan kadar albuminuria rata-rata berdasarkan ACR adalah $722,53 \pm 1854,96 \mathrm{mg} / \mathrm{g}$. Responden laki-laki lebih rendah dibanding perempuan yaitu 667,8 $\mathrm{mg} / \mathrm{g}$ berbanding $777,2 \mathrm{mg} / \mathrm{g}$.

3. Tidak terdapat hubungan yang bermakna antara TGF- $\beta 1$ pada Nefropati Diabetik (ND) dengan kadar albumin dalam urin yang dihitung berdasarkan rasio albumin dan creatinin urin (ACR) $(p=0,066)$.

\section{Saran}

1. Perlu dilakukan penelitian lanjutan yang menghubungkan antara kadar TGF- $\beta 1$ dalam darah dan urin pasien DM tipe-2 dengan ND.

2. Perlu diteliti faktor2 yang mempengaruhi kadar TGF- $\beta 1$ dalam darah pasien DM tipe-2 dengan ND.

\section{DAFTAR PUSTAKA}

1. Obineche EN, Adem A. Update in diabetic nephropathy. Int J Diabetes \& Metabolic; 2005 13:1-9.

2. Christanto, et al. Kapita Selekta Kedokteran. Ed IV. Jakarta : Media Aeskulapius; 2014.

3. Liu L., Guo Q., Li C., Dong W., and Sun G., 2015. Novel Biomarkers for Early Diagnosis and Progression of Diabetic Nephropathy, ARC Journal of Diabetes and Endocrinology 1(1): $14-30$.

4. Chang AS, Hathaway CK, Smithies O, Kakoki M. Transforming Growth Factor- $\beta 1$ and Diabetic Nephropathy. United States: American Physiological Society; 2015

5. Kim S.S., Kim J.H., Kim I.J.,2016. Current Challenges in Diabetic Nephropathy : Early Diagnostic and Way to Improve Outcomes. Endocrinol Metab $31 ; 245-253$

6. Johnson CA, Levey AS, Coresh J, Levin A, Lau J, Eknoyan G. Clinical practice guidelines for chronic kidney disease in adult: Part II. Glomerular filtration rate, proteinuria, and other markers. Am Fam Physician. 2004;70(6):1091-7.

7. Tagle R, Acevedo M, Vidt DG. Microalbuminuria: is it a valid predictor of cardiovascular risk? Cleve Clin J Med. 2013;70(3):225-61. 